DOI: $10.17951 / \mathrm{m} .2019 .4 .81-89$

\begin{tabular}{cc}
\hline & ANNALES \\
& UNIVERSITATIS MARIAE CURIE-SKłODOWSKA \\
LOL. IV & SECTIO M \\
\hline
\end{tabular}

\author{
Robert Bański \\ Maria Curie-Skłodowska University in Lublin \\ rbanski@wp.pl \\ ORCID ID: http://orcid.org/0000-0003-3148-2818
}

\title{
Energy Companies in Poland
}

\section{Introduction}

An analysis of energy companies participating in Poland's energy policy system is worth conducting for several reasons. First, energy sectors crucial to energy security - mining, transmission and distribution - are under state control ${ }^{1}$. Second, energy companies actively participate in the implementation of strategy ${ }^{2}$, and in the co-creation and realisation of state energy policy - which puts them in a key position within the entire system ${ }^{3}$. Third, energy companies are the primary implementers of policies regarding secure energy supply, interests protection, and environmental protection ${ }^{4}$. It is also worth pointing out that State Treasury-co-owned energy companies are active in establishing and

1 P. Szmitkowski, A.Gil-Świderska, S.Zakrzewska, Electrical energy infrastructure in Poland and its sensitivity to failures as part of the energy security system, „Polityka Energetyczna” 2019, vol.22, issue 2, p.59-88.

2 Por. Polityka energetyczna Polski do 2030 r., Ministerstwo Gospodarki, Warszawa 2009.

3 Zob. A. Komorowska, J. Kamiński, A review of the 2018 Polish capacity market auctions , "Polityka Energetyczna” 2019, vol. 22, issue 2, p. 77-88; J. Trubalska, Miejsce wegla brunatnego w bilansie energetycznym Polski, [w:] Wybrane aspekty bezpieczeństwa w ujęciu instytucjonalnoprawnym, red. Trubalska J., Paździor M., Wojciechowski Ł., WSEI, Lublin 2019, p.131-138.

4 J. Trubalska, Rywalizacja państwo surowce energetyczne, [w:] Wspótczesne bezpieczeństwo ekonomiczne i społeczno-kulturowe. Wymiar międzynarodowy, red. Marta Gębska, Akademia Sztuki Wojennej, Lublin 2017, p. 179-182. 
enacting specific objectives resulting from the energy policy: diversification of energy carriers, diversification of fuels sourcing, as well as energy infrastructure development and modernisation.

The main regulation for energy companies in Poland is the Energy Law Act. This Act defines an energy company as an economic entity engaged in production, processing, storage, transmission, or distribution of fuels or energy, or trading them, or transmission of carbon dioxide. Additionally, the Act indicates the category of vertically integrated undertaking, being an energy enterprise or a group of enterprises engaged in the following activities with respect to gaseous fuels: transmission or distribution or storage or liquefication and generation or sale of such fuels, or with respect to electricity: transmission or distribution and generation or sale of such energy ${ }^{5}$. The entities constituting Polish energy policy system are, in the broad sense, all entities supplying gaseous fuels to the gas system, or supplied from that system, as well as those supplying electricity to the electricity system, or supplied from that system, which the Act defines as system users. In addition, the Act indicates another category, that of the importer, which it defines as a natural person, legal entity, or an organization that is not a legal entity that directly or indirectly imports liquid fuels, except for imports of liquid fuels as part of international trade requiring a license, or meant for use during transport and carried in standard fuel tanks ${ }^{6}$.

Energy companies engaged in transmission or distribution of gaseous fuels or electricity are bound by the Act to prepare development plans aimed to satisfy the current and future demand for gaseous fuels or energy for no less than 3 years ${ }^{7}$. The information contained in the plan concerns both the predicted delivery of gaseous fuels or energy, developing and modernisation of the network, and prospective new sources of gaseous fuels or energy, including cross-border undertakings ${ }^{8}$.

Analysis of energy enterprises operating in the natural gas sector

In the analysed system, companies function as part of energy groups. The decision to consolidate energy companies was meant to establish stable and strong energy enterprises that could compete on the EU market. Consolidation involved entities owned by the State Treasury, organised into four energy

\footnotetext{
Article 3(12a) of the Energy Law Act.

6 Article 3(12b) and 3(12c) of the Energy Law Act

Article 16(1) of the Energy Law Act

8 Article 17(7) of the Energy Law Act
} 
groups: Polska Grupa Energetyczna (PGE), Tauron - Polska Energia Group (South), Enea Group (Centre), and Energa Group (North). Other enterprises of key importance to Polish economy and energy security, and, consequently, to the energy policy system are: Polskie Górnictwo Naftowe i Gazownictwo S.A. (PGNiG) Capital Group, Gas Transmission Operator Gaz-System S.A., Polskie LNG S.A., PERN Group, and PGE Capital Group.

The entity tasked with implementing the overall Polish energy security policy is the PGNiG Capital Group, which is responsible for:

- search and extraction of natural gas,

- seach for petroleum,

- import of natural gas,

- fuels storage,

- natural gas and petroleum trading,

- distribution of gaseous and liquid fuels,

- production of heat and electric power'.

PGNiG Group is the capstone for implementing energy policy and for Polish energy security. Its tasks in securing Poland's fuel needs are fulfilled through exploitation of domestic deposits and through imports. Its operations are shaped by dependent and independent variables impacting the energy policy system of Poland. The Group is composed of commercial law companies with diverse operations (production, trade, and services), the mother company being PGNiG S.A., with 34 subsidiaries (Fig. 1). Its core business are petroleum and natural gas prospecting and exploitation, both domestically and abroad, and their subsequent sale. PGNiG Capital Group is the largest importer of natural gas to Poland. Its additional operations include trading on the electricity markets and $\mathrm{CO}_{2}$ emission allowance markets, as well as certification of energy origin. Since the biggest company in the group is PGNiG S.A., much of the group's activity consists in LNG regasification at terminals in Ełk and Olecko. Other activities of PGNiG Capital Group include distribution and production. The first of these is the transmission of natural gas, and development and modernisation of the transmission network. Distribution is handled by the subsidiary company Polska Spółka Gazownictwa Sp. z o.o. The second area is that of production of electricity, heat, cold, compressed air, as well as heat distribution - the main subsidiary performing these being PGNiG TERMIKA ${ }^{10}$.

9 The website of PGNiG Capital Group: http://pgnig.pl/pgnig/o-nas/grupa-kapitalowapgnig http://pgnig.pl/, accessed 12.12.2018.

${ }^{10}$ Ibid. 
Because of its key position in energy security, the goals of the new PGNiG CG Strategy for 2017-2022 with perspective until 2026, on the level of key areas of operation of PGNiG CG, are very consequential. The Strategy for prospecting and extracting has set a goal of increasing proven reserves by approximately $35 \%$, and increasing hydrocarbons extraction by approximately $41 \%{ }^{11}$. It is worth noting that lowering the cost of exploration and establishing and enhancing the state of resources is considered an important goal in its own right. As far as natural gas trading is concerned, the plan predicts a further diversification of sources, creation of a competitive supply portfolio, and an increase in sales of about 7\%. In the area of storage, the Group aims to improve efficiency and to secure available storage capacity to meet the demand. Additionally, NG distribution volume is projected to increase by approximately $16 \%$, and about 300 thousand new households are estimated to become connected to the gas network. The Group also plans to increase heat and energy sales by about $20 \%{ }^{12}$. In the area of technological advantages on the market, the Group intends to increase involvement and enhance efficiency in research, development and innovation, with future expense being estimated at PLN 680 million $^{13}$.

In turn, Gaz-System S.A. is a company mainly involved in transferring gaseous fuels in the domestic network. The company is given specific tasks - first, ensuring coordinated and efficient transfer inside the network, while maintaining the required reliability of gaseous fuels deliveries, as well as their quality ${ }^{14}$. The specific activities of this company are therefore concentrated on both the maintenance and development of the existing transfer network, as well as the removal of so-called energy islands existing in Poland. Additional company activities are discharged through development of transmission infrastructure at the Community level, which bolsters integration in natural gas transfer markets. The company is an instrument for the energy system fulfilling its function as a transit country for natural gas within the European Union. Secondly, Gaz-System S.A. ensures equal access to the transfer network for all entities in the natural gas market. In practice, this means supplying operators of transfer, storage, distribution and LNG systems with information enabling them to both transport and store natural gas as required for the safe and effective operation

11 Strategia GK PGNiG na lata 2017-2022 z perspektywa do 2026 r., PGNiG, Warszawa 2017, dostępne na: http://pgnig.pl/documents/10184/1758740/Strategia+GK+PGNiG+na+lat $\mathrm{a}+2017 \% \mathrm{E} 2 \% 80 \% 932022+\mathrm{z}+$ perspektyw $\%$ C4\% $85+$ do $+2026+$ r.pdf/080f745e-26a2-4348-b66c59fcf204c36c, accessed 12.01.2019

12 Ibid.

${ }_{13}$ The website of PGNiG: http://pgnig.pl/, accessed 12.12.2018.

14 The Website of Gaz -system, http://www.gaz-system.pl/, accessed 7.03.2019 
Figure 1. PGNiG Capital Group as of 30 June 2018 - direct and indirect interest

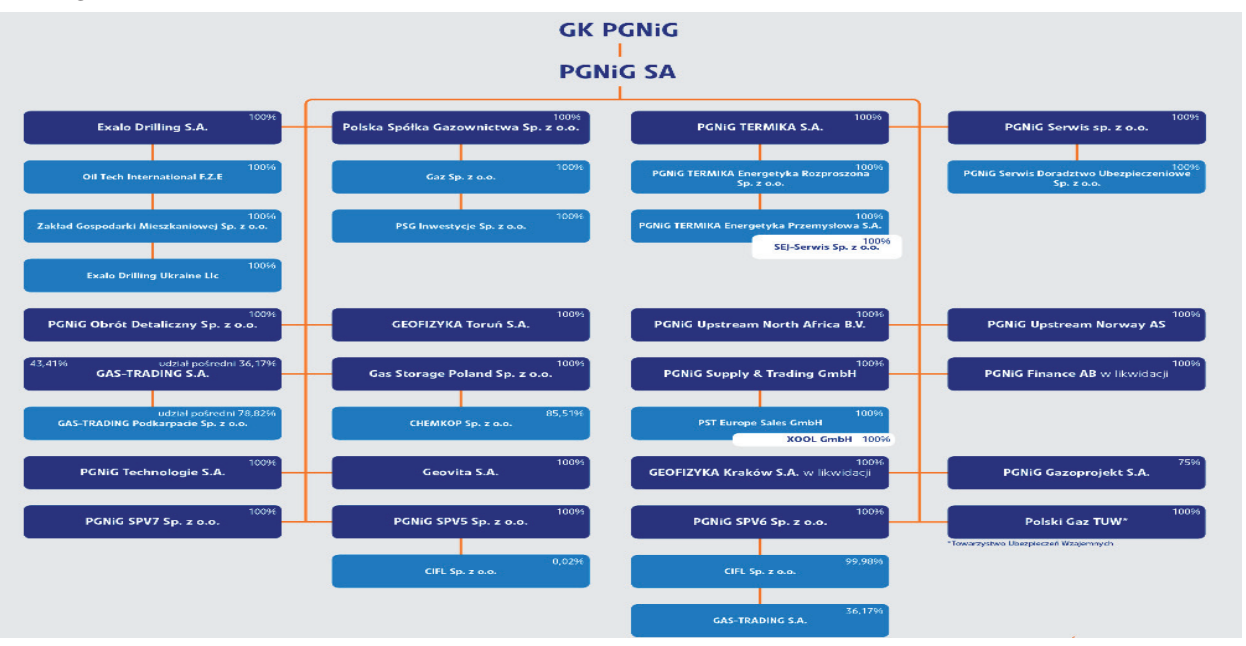

Source: http://pgnig.pl/pgnig/o-nas/grupa-kapitalowa-pgnig, accessed: 19.03.2019 r.

of those systems. Thirdly, the company fills a key and unique role storing natural gas ${ }^{15}$. Gaz-System S.A. holds a license to transfer gaseous fuels until 2068. As said above, the company is a key implementer of energy policy in the sector of natural gas. The company's operations extend beyond Poland's borders, since it is an active participant in the integration of the EU transit system. Thereby its operations are part of the strategies adopted at the national and EU level, making the company an actor in creating a competitive natural gas market, and a modern network of pipelines in Poland ${ }^{16}$.

In addition, Gaz-System S.A. is the owner of Polskie LNG S.A., the company responsible for building, developing and operating liquid natural gas terminals in Świnoujście. Polskie LNG was formed by PGNiG S.A., and put in the ownership of Gaz-System S.A. by the Resolution of the Council of Ministers of 19 August 2008 , and became a joint-stock company on 1 January 2010. This, alongside the above-mentioned expansion of the transfer network, is yet another means to diversify the sources and routes of natural gas coming into Poland. Polskie LNG S.A. owns the President Lech Kaczyński LNG Terminal in Świnoujście, and holds a license to liquefy and regasify LNG until 31 December 2030. Since 2016, the company is working to diversify the sources of natural gas for Poland, which the terminal's operation materially realises and thereby strengthens Poland's energy

\footnotetext{
15 Ibid.

16 Ibid.
} 
security, fulfilling the goals set out in the document Polityka energetyczna Polski do 2030 r. (Poland's Energy Policy Through 2030). Critically, the LNG terminal in Świnoujście fits the framework of the European North-South Gas Corridor. The investment is important both for the state system, as well as for the region of Baltic Sea and Central Europe, and for Europe as a whole, since it creates a new framework of cooperation in the sector of natural gas for states that joined the EU after 2014. It is worth pointing out that one of the assumptions of the investment is connecting the terminal in Swinoujście with Adria LNG terminal in Croatia ${ }^{17}$. Expanding the LNG terminal in Świnoujście will allow purchase of natural gas independently of the Russian Federation, allowing a radical and qualitative shift in gas supply for the region.

Analysis of energy enterprises operating in the oil sector

When it comes to petroleum, the market leader in Poland is PERN group, whose main task is managing the network of petroleum pipelines. Additionally, the group possesses approximately 3.5 million $\mathrm{m}^{3}$ of storage volume for liquid fuels. The group manages a sea terminal with the capacity of 40 million tonnes per year, and 4 million tonnes of fuel per year. The group's operations are in two segments: transport and storage of petroleum and fuels, and reloading and storage of fuels for distributors and traders ${ }^{18}$. The PERN S.A. Capital Group is composed of: NAFTOPORT Sp. z o.o., Naftoserwis Sp. z o.o., Naftor Sp. z o.o., and "Siarkopol" Gdańsk S.A. Another subsidiary of the group is Sarmatia Sp. z o.o. - a study company formed to investigate the viability of the proposed Euro-Asian Oil Transport Corridor (EAOTC) along the route Baku - Odessa - Brody - Płock - Gdańsk ${ }^{19}$.

The largest enterprise in the electricity sector is PGE Capital Group, whose purpose is to ensure security and growth based on reliability of supply of electricity $^{20}$. It is composed of 12 companies, including: PGE Energia Odnawialna S.A., PGE EJ 1 Sp. z o.o. and PGE Górnictwo i Energetyka Konwencjonalna S.A. The main function of the first of these companies is producing energy from Renewable Energy Sources (RES) and providing Ancillary Control Services. Currently, the group manages four power stations, with the total power of generators, including hydropower and wind power stations, of $2188.972 \mathrm{MW}^{21}$. The second

${ }^{17}$ J. Trubalska, Bezpieczeństwo energetyczne Rzeczypospolitej Polskiej, PTG, Kraków 2015, p. 207.

18 The Website of PERN, https://pern.pl, accessed 02.02.2019.

19 Ibid.

20 The website of PGE, https://www.gkpge.pl/relacje-inwestorskie/Grupa/Kim-jestesmy, access 16.09.2019

${ }^{21}$ The website of PGE, https://pgeeo.pl/O-Spolce, access 18.09.2019 
Figure 2. PERN Capital Group

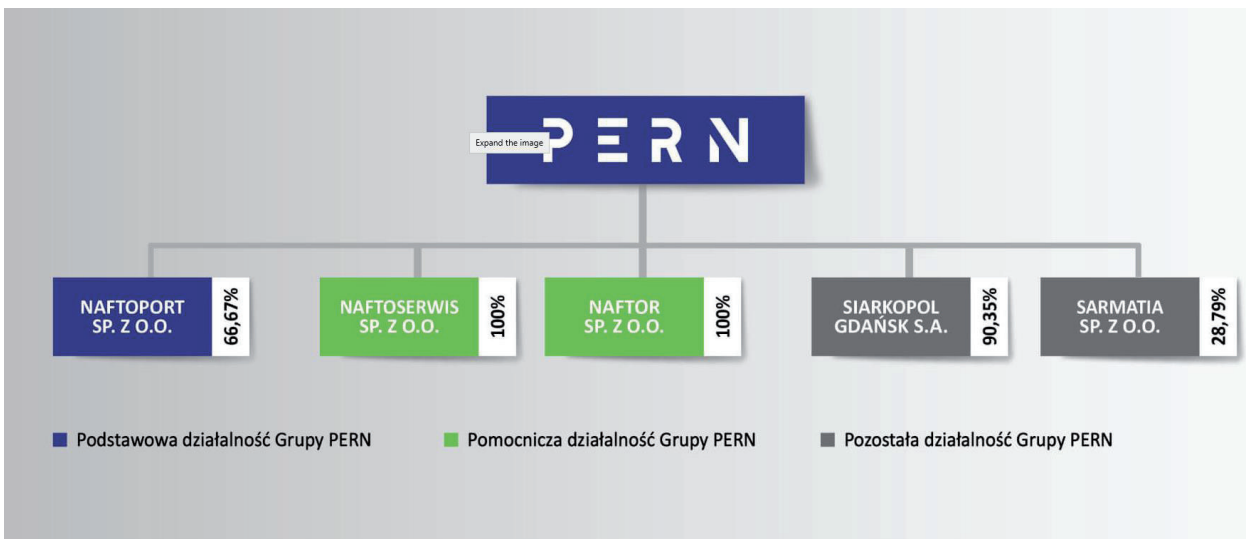

Source: https://pern.pl/grupa-kapitalowa/\#prettyPhoto, accessed: 19.03.2019

Figure 3. PGE Capital Group

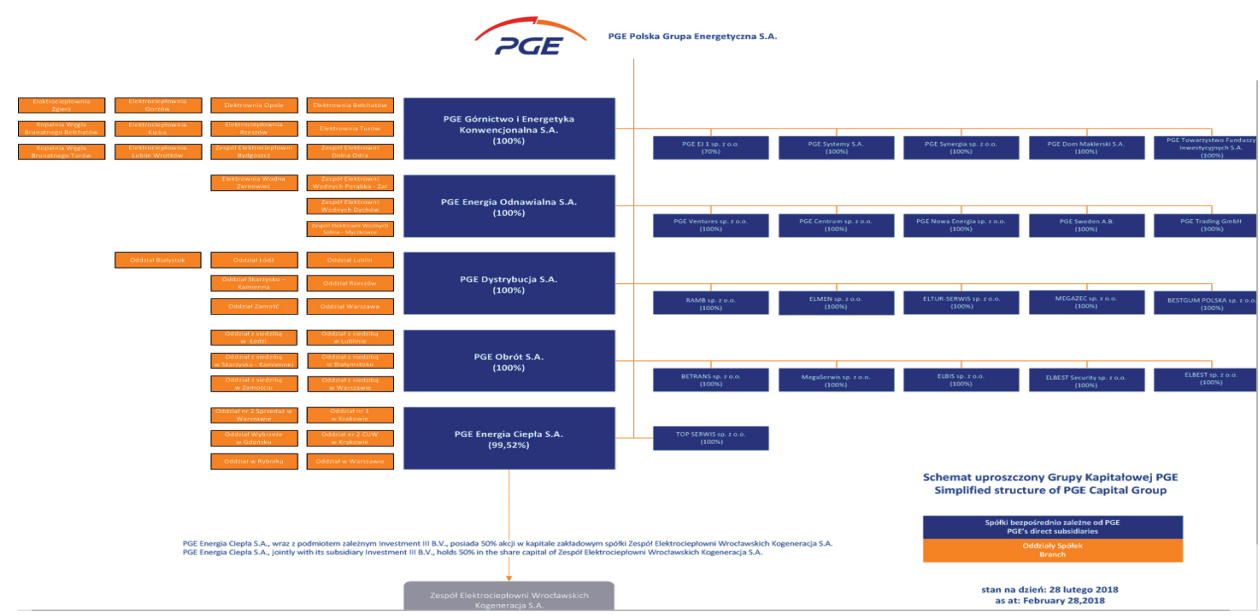

Source: https://www.gkpge.pl/relacje-inwestorskie/Grupa/Kim-jestesmy, accessed: 19.03.2019

of the three abovementioned companies is a special purpose vehicle formed to make real the government programme to construct a nuclear power station with the power output of $3750 \mathrm{MWe}^{22}$. Lastly, PGE GiEK S.A. is engaged in efficient lignite mining and power and heat production, thereby contributing to Poland's energy security by providing a constant and dependable supply of electricity. 


\section{Summary}

The analysis of energy companies functioning in the energy policy system presented above warrants the conclusion that these companies are capable of realising the energy policy of the state. Their operations go beyond the framework of joint design of energy policy, since they also fill key roles in making active the specific tasks set out in strategic documents. Their individual work in diversifying the transfer of resources, fuel sources and energy carriers is analysed in chapter 5 . Here, suffice it to say that the changes in ownership structure and legal status have contributed to the competitiveness of these energy companies on both European and global markets. It is also worth emphasizing that the analysed system would not effectively function without the activity of Poland's energy companies efficiently discharging their assigned roles and fulfilling their key contributions to energy security and energy policy at large.

\section{Bibliography}

\section{Sources}

- Polityka energetyczna Polski do 2030 r., Ministerstwo Gospodarki, Warszawa 2009.

- Energy Law Act, Dz.U. 1997, Nr 54, poz. 348.

- Strategia GK PGNiG na lata 2017-2022 z perspektywa do 2026 r., PGNiG, Warszawa 2017, http://pgnig.pl/documents/10184/1758740/Strategia+GK+PGNiG+na+lata+2 017\%E2\%80\%932022+z+perspektyw\%C4\%85+do+2026+r.pdf/080f745e-26a2-4348b66c-59fcf204c36c.

- The website of PGNiG Capital Group http://pgnig.pl/pgnig/o-nas/grupa-kapitalowapgnig http://pgnig.pl/.

- The website of PGNiG http://pgnig.pl/

- The Website of Gaz - system, http://www.gaz-system.pl/

- The Website of PERN, https://pern.pl/

- The website of PGE, https://www.gkpge.pl/relacje-inwestorskie/Grupa/Kim-jestesmy/

- The website of PGE, https://pgeeo.pl/O-Spolce,

\section{Literature}

- Szmitkowski A., Gil-Świderska A., Zakrzewska S., Electrical energy infrastructure in Poland and its sensitivity to failures as part of the energy security system, „Polityka Energetyczna" 2019, vol.22, issue 2.

- Komorowska A., Kamiński J., A review of the 2018 Polish capacity market auctions , "Polityka Energetyczna" 2019, vol. 22, issue 2.

- Trubalska J., Miejsce wegla brunatnego w bilansie energetycznym Polski, [w:] Wybrane aspekty bezpieczeństwa w ujęciu instytucjonalno-prawnym, red. Trubalska J., Paździor M., Wojciechowski Ł., WSEI, Lublin 2019.

- Trubalska J., Rywalizacja państw o surowce energetyczne, [w:] Współczesne bezpieczeństwo ekonomiczne i społeczno-kulturowe. Wymiar międzynarodowy, red. Marta Gębska, Akademia Sztuki Wojennej, Lublin 2017.

- Trubalska J., Bezpieczeństwo energetyczne Rzeczypospolitej Polskiej, PTG, Kraków 2015. 


\begin{abstract}
The aim of the article is to analyze energy companies in Poland and indicate their place in the current energy policy system. Taking up the subject results from several premises. First of all, the energy sector is of key importance for the functioning of states, and also its condition has an impact on energy security. Secondly, energy infrastructure is critical infrastructure. Thirdly, the state strategy in the energy plane is implemented through energy companies, and thus these are key and necessary entities that implement the state energy policy.
\end{abstract}

Key words Energy policy, energy companies, energy security

\title{
Polskie spółki sektora energetycznego
}

Abstrakt: Celem artykułu jest analiza przedsiębiorstw energetycznych w Polsce i wskazanie ich miejsca w systemie polityki energetycznej. Podjęcie tematu, wynika z kilku przesłanek. Po pierwsze, sektor energii ma kluczowe znaczenie dla funkcjonowania państw, a także jego kondycja ma wpływ na bezpieczeństwo energetyczne. Po drugie, infrastruktura energetyczna ma charakter infrastruktury krytycznej. Po trzecie, za pośrednictwem przedsiębiorstw energetycznych realizowana jest strategia państwa w płaszczyźnie energetycznej, a co za tym idzie są kluczowymi i niezbędnymi podmiotami, które realizują politykę energetyczną państwa.

Słowa klucze Polityka energetyczna, przedsiębiorstwa energetyczne, bezpieczeństwo energetyczne 